\title{
Multivariate Geospatial Feature of the Soil Attributes of Archaeological Dark Earth in Novo Aripuanã, AM
}

\author{
José Maurício da Cunha ${ }^{1}$, Milton César Costa Campos ${ }^{1}$, Alan Ferreira Leite de Lima ${ }^{1}$, \\ Elilson Gomes de Brito Filho ${ }^{1}$, Douglas Marcelo Pinheiro da Silva ${ }^{1}$, Fernando Gomes de Souza ${ }^{2}$, \\ Lucivânia Izidoro da Silva ${ }^{1}$, Maria Clécia Gomes Sales ${ }^{1}$ \& Ivanildo Amorim de Oliveira ${ }^{3}$ \\ ${ }^{1}$ Institute of Education, Agriculture and Environment, Federal University of Amazonas, Humaitá, AM, Brazil \\ ${ }^{2}$ Federal Institute of Education, Science and Technology of Rondônia, IFRO, Brazil \\ ${ }^{3}$ Federal Institute of Education, Science and Technology of Pará, IFPA, Brazil
}

Correspondence: Elilson Gomes de Brito Filho, Institute of Education, Agriculture and Environment, Federal University of Amazonas, Humaitá, AM, 69800-000, Brazil. Tel: 55-979-8112-1704. E-mail: bfsambiente@gmail.com

Received: January 16, 2019

Accepted: April 8, $2019 \quad$ Online Published: June 15, 2019

doi:10.5539/jas.v11n8p196

URL: https://doi.org/10.5539/jas.v11n8p196

\begin{abstract}
Changes in natural ecosystems for the use and management of soil can have negative consequences, favoring the appearance of areas susceptible to physical degradation. This work aimed to evaluate changes on the soil properties in Archaeological Dark Earth environments preserved under pigeon pea cultivation and pasture, using multivariate geostatistics technique. Sampling meshes were delimited with regular spacings with 88 sample points per mesh and then georeferenced. Soil samples and volumetric rings were collected in the layers $0.0-0.05$ $\mathrm{m}, 0.05-0.10 \mathrm{~m}$ and $0.10-0.20 \mathrm{~m}$, for the determinations of the physical attributes and soil organic carbon. The main components main components $1(\mathrm{MC} 1)$ and main components $2(\mathrm{MC} 2)$ were characterized by attributes related to the stability of the aggregates (geometric average diameter (GAD), weighted average diameter (WAD) and aggregate classes) and the related soil structure taxes, respectively, with a variability of soil attributes under forest influenced by values above the mean for both main components. Land use under pigeon pea little influenced the variability of the main components, presenting values of the attributes related to these components near the mean values, while the soil under pasture promoted influence only to the attributes related to main components 2 (MC2).
\end{abstract}

Keywords: Southern Amazon, soil physics, factorial analysis

\section{Introduction}

The Southern Amazon region covers an area with great diversity of geological material, thereby forming soils of different natures, among these are the anthropic soils known as Indian Black Earth (IBE), IBE are soil units that have dark coloration, high natural fertility and high organic carbon content (Glaser \& Birk, 2012).

Agricultural practices have a direct effect on the physical quality of the soil, as well as significant interference in the carbon content. The spatial variability of soil attributes in natural and processed environments, becomes important for the understanding of the behavior of variations of soil attributes in relation to different management systems (Alves, Queiroz, Alcântara, \& Reis, 2014; Oliveira, Campos, Freitas, \& Soares, 2015; Soares et al., 2016).

There is consensus that the water content in the soil, bulk density, total porosity, macro and microporosity and soil penetration resistance indicates the state in which the ground structure lies and serve as indicators of the physical quality (Andrade, Araújo, Rosa, Gomes, \& Lobato, 2009; Aratani, Freddi, Centurion, \& Andrioli, 2009; Sales, Portugal, Moreira, Kondo, \& Pegoraro, 2016). Consequently, an ideal soil structure provides better conditions for plant development, sufficient and continuous pore space for the movement of water and gases, and low soil resistance to root penetration, so as not to disrupt its growth.

Thus, spatial variability is widely used for a better understanding of the aspects related to the physical and chemical characteristics of the soil, besides correlating the interrelationships of these attributes with systems of land use and management (Aquino et al., 2015; Oliveira, Campos, Freitas, \& Soares, 2015). The use of 
geostatistical techniques allow us to show patterns of spatial variability of soil attributes and to identify which attributes have the best spatial correlations within each environment and thereby identify areas susceptible to degradation or possible changes attributed to anthropogenic activities.

However, a very large number of variables involved in all the dynamics of the system soil-plant-atmosphere becomes very complex as to decision making. Thus, an option of analysis of the spatial variability for the set of soil variables is the use of multivariate geostatistics (Silva, Lima, Xavier, \& Teixeira, 2010; José et al., 2013; Alves, Queiroz, Alcântara, \& Reis, 2014).

The objective of this work was to evaluate the spatial variations of soil attributes in environments of Indian Black Earth preserved and under cultivation of pigeon pea and pasture using a multivariate geostatistics technique in Novo Aripuanã, AM.

\section{Material and Methods}

The study was conducted in an Argisol Eutrophic Yellow Latosol in Novo Aripuanã, Amazon, Brazil, located along the Transamazon Highway (BR-230) (Figure 1). The climate of the region is Tropical Rainy, presenting a short dry period. The average rainfall varies between 2,250 and $2,750 \mathrm{~mm}$, with a rainy period between October and June. Average annual temperatures range from 25 to $27{ }^{\circ} \mathrm{C}$ and the relative humidity is between 85 and $90 \%$.
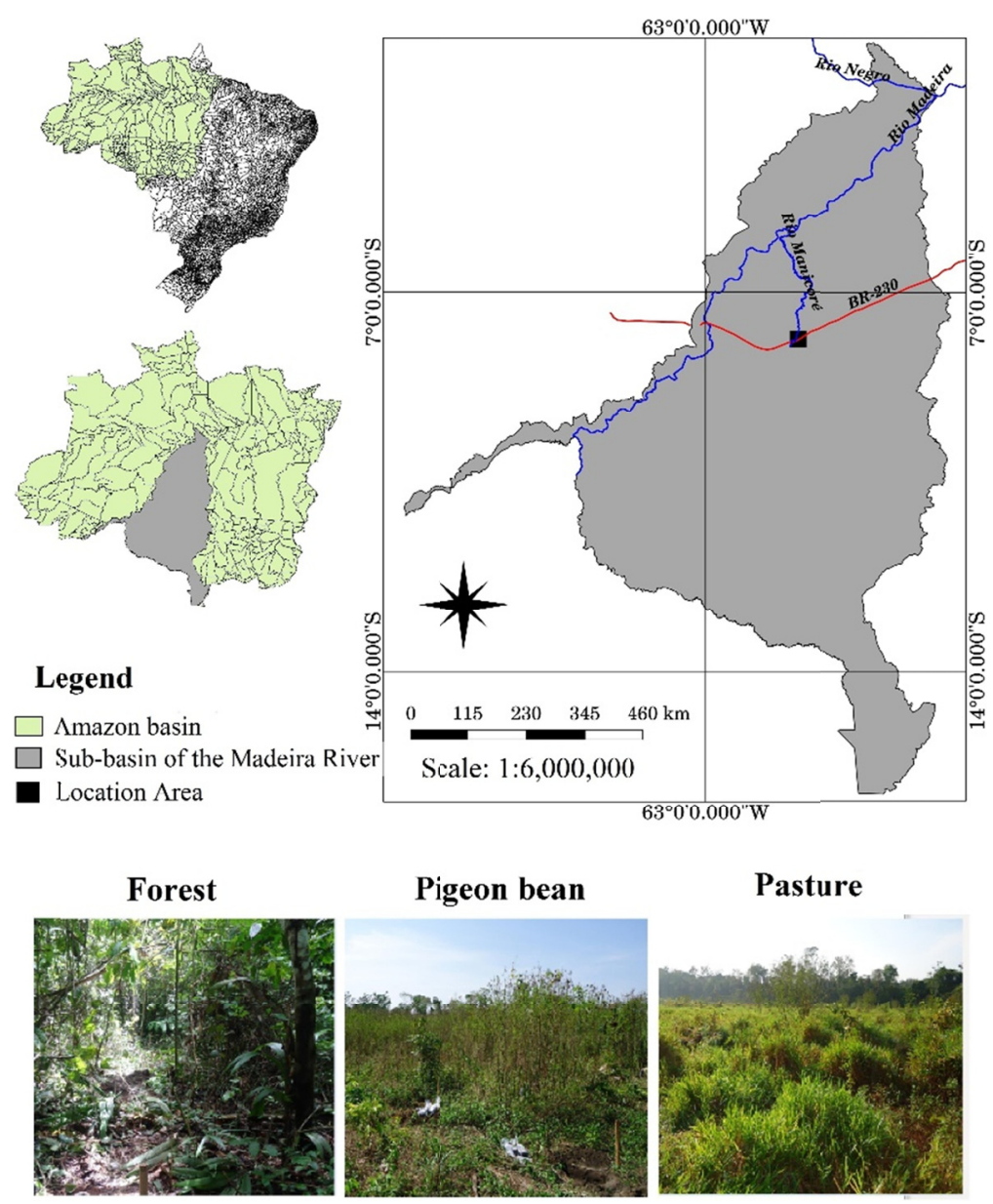

Figure 1. Location of study areas in Novo Aripuanã, Amazon, Brazil

The study included three types of cover under the one soil spot of Indian Black Earth, the first being a forest fragment; the second is under the cultivation of pigeon peas (Cajanus cajan); and a third with Brachiaria (Brachiaria brizanta). A sample mesh was delimited in each area, with collection points georeferenced with GPS equipment for mapping the areas. Two areas with 88 collection points and one area (pigeon pea) with 90 collection points. The mesh sizes were $2500 \mathrm{~m}^{2}$ for forest, $1700 \mathrm{~m}^{2}$ for pigeon pea and $4800 \mathrm{~m}^{2}$ for pasture, with 
regular spacings between the soil sampling points of $6 \times 6 \mathrm{~m}, 4 \times 5 \mathrm{~m}$ and $8 \times 8 \mathrm{~m}$, respectively, totaling 266 samples.

Soils with preserved structure and volumetric rings were collected in the $0.0-0.20 \mathrm{~m}$ layer for the determination of physical attributes and organic carbon. The samples with a preserved structure in the form of a soil clod were dried in the shade and then manually discharged and passed through a $9.51 \mathrm{~mm}$ diameter sieve and retained in the $4.76 \mathrm{~mm}$ sieve, for analysis of stability of aggregates. Samples that passes on the $2.00 \mathrm{~mm}$ sieve, were used in the organic matter analysis and, after passed through a $250 \mu \mathrm{m}$ sieve.

The method used for the separation and stability of the aggregates was determined according to Kemper and Chepil (1965), with modifications in the following classes of diameter: 4.76-2.0 mm; $2.0-1.0 \mathrm{~mm} ; 1.0-0.50 \mathrm{~mm}$; $0.50-0.25 \mathrm{~mm} ; 0.25-0.125 \mathrm{~mm} ; 0.125-0.063 \mathrm{~mm}$. The aggregates were placed in contact with the water on the $2.00 \mathrm{~mm}$ sieve and submitted to vertical shaking in Yoder apparatus (SOLOTEST, Bela Vista, São Paulo, Brazil) for $15 \mathrm{~min}$. The materials retained in each sieve class were placed in an oven at $105{ }^{\circ} \mathrm{C}$, and then measured on a digital scale.

The results were expressed in terms of the percentage of aggregates retained in each of the sieve classes and the stability of the aggregates evaluated by the weighted average diameter (WAD-Equation 1) and the geometric average diameter (GAD-Equation 2), defined by:

$$
\begin{gathered}
\mathrm{WAD}=\frac{\sum_{\mathrm{i}=1}^{\mathrm{N}} \mathrm{n}_{\mathrm{i}} \mathrm{D}_{\mathrm{i}}}{\sum \mathrm{n}_{\mathrm{i}}} \\
\mathrm{GAD}=10^{\frac{\sum_{\mathrm{i}=1}^{\mathrm{N}} \mathrm{n}_{\mathrm{i}} \log \mathrm{D}_{\mathrm{i}}}{\sum \mathrm{n}_{\mathrm{i}}}}
\end{gathered}
$$

where, $n_{i}=\%$ of the aggregates retained in a given sieve; $D_{i}=$ average diameter of a given sieve; $N=$ number of sieve classes.

The particle size analysis was conducted by the method of the pipette, using a normal $\mathrm{NaOH}$ solution as chemical dispersant and mechanical stirring apparatus at high speed for $15 \mathrm{~min}$, following the methodology proposed by Embrapa (2011). The soil density (SD), macroporosity (MaP) and microporosity (MiP), total pore volume (TPV) and gravimetric humidity $(\mathrm{GH})$ were measured according to the Embrapa (2011) methodology, using soil samples in volumetric rings. The organic carbon (OC) was determined by the method proposed by Yeomans and Bremner (1988).

Considering the multivariate structure contained in the data, multivariate statistical techniques were used to establish physical attributes with discriminatory power and that could be considered potential indicators of environmental changes and to verify similarities among the different soils studied in the attempt to group them using the attributes evaluated.

An analysis of factors was carried out which allows to relate a set of variables to be explained in terms of a limited number of new variables and, we chose to use the main component extraction calculated from the correlation matrix between variables. To facilitate interpretation, we used the orthogonal rotation method called Varimax (Manly, 2008).

The analysis of factors was complemented with the main components (MC), to obtain a smaller set of linear combinations of the variables selected in the factor analysis to which they preserved most of the information provided by the original variables (Silva et al., 2010). This analysis makes it possible to evaluate how the attributes interact qualitatively at the same time, whose original values were normalized to mean equal zero and variance equal to unity, in order to compose the variables used in the main components analysis. The criterion adopted for choosing the number of components was to select those that presented eigenvalues above 1.00 and were able to synthesize an accumulated variance above 70\% (Manly, 2008). All multivariate statistical analyzes were processed in the software STATISTICA, version 7.0 (Statsoft, 2004). It was identified the soil attributes that most discriminate the environments, regarding the use and management of the soil in relation to the forest environment, through factorial analysis that indicated significant results $(\mathrm{KMO}=0.78$ and $\mathrm{p}<0.05$, Barlett's sphericity test) and, therefore, is adequate for the evaluated attributes.

To determine the existence of spatial dependence, semivariograms were modeled using geostatistical analysis (Isaaks \& Srivastava, 1989). Under the theory of the intrinsic hypothesis, the experimental semivariogram was estimated using the Equation 3:

$$
\hat{\mathrm{y}}(\mathrm{h})=\frac{1}{2 \mathrm{n}(\mathrm{h})} \sum_{\mathrm{i}=1}^{\mathrm{n}(\mathrm{h})}\left[\mathrm{Z}\left(\mathrm{x}_{\mathrm{i}}\right)-\mathrm{Z}\left(\mathrm{x}_{\mathrm{i}}+\mathrm{h}\right)\right]^{2}
$$


where, $\hat{\gamma}(h)$ : value of the half-life for a distance $\mathrm{h} ; n(h)$ : number of pairs involved in the semivariance calculation; $Z\left(x_{i}\right)$ : value of attribute $Z$ in the position $x_{i} ; Z\left(x_{i}+h\right)$ : value of attribute $Z$ separated by a distance $h$ from position $x_{i}$.

In the analysis of the degree of spatial dependence (DSP) of the studied variables, the classification of Cambardella et al. (1994), where values of DSP $\left[\left(C_{0} /\left(C_{0}+C_{1}\right) \times 100\right]\right.$ less than $25 \%$ are considered strong spatial dependence, values between 25 and $75 \%$ indicate moderate spatial dependence and values greater than $75 \%$ low spatial dependence. In the elaboration of the maps of spatial distribution of the variables, the scores of the samples referring to MC1 were used with the aid of the software Surfer 8.0 (Golden Software Inc., 1999).

\section{Results and Discussion}

Soil attributes were significantly related (Table 1) to each other. OC showed a negative correlation with $\mathrm{Sd}$, indicating high $\mathrm{OC}$ contents for low Sd values, which justifies it as an important component in soil structuring. Similar behavior was observed in IBE environments under cocoa cultivation in a Eutrophic Yellow Argisol (Silva et al., 2016). OC is also considered as an important element in the aggregation of soil particles, which has been confirmed by the significant correlation with GAD and WAD aggregate classes.

Table 1. Spearman correlation coefficient $(n=798)$ of the soil attributes of Indian Black Earth in Novo Aripuanã, Amazon, Brazil

\begin{tabular}{|c|c|c|c|c|c|c|c|c|c|c|c|c|c|}
\hline & Ds & $\mathrm{MaP}$ & MiP & TPV & $\mathrm{GH}$ & $\mathrm{OC}$ & Sand & Silt & Clay & GAD & WAD & $>2.0$ & $2.0-1.0$ \\
\hline $\mathrm{MaP}$ & $-0.73^{*}$ & 1.00 & & & & & & & & & & & \\
\hline MiP & 0.01 & $-0.51^{*}$ & 1.00 & & & & & & & & & & \\
\hline TPV & $-0.86^{*}$ & $0.77^{*}$ & $0.10^{*}$ & 1.00 & & & & & & & & & \\
\hline $\mathrm{GH}$ & $-0.60^{*}$ & 0.06 & $0.77^{*}$ & $0.61^{*}$ & 1.00 & & & & & & & & \\
\hline $\mathrm{OC}$ & $-0.47^{*}$ & $0.21^{*}$ & $0.29^{*}$ & $0.43^{*}$ & $0.52^{*}$ & 1.00 & & & & & & & \\
\hline Sand & $0.47^{*}$ & $-0.22^{*}$ & $-0.16^{*}$ & -0.37 & $-0.41^{*}$ & $-0.40^{*}$ & 1.00 & & & & & & \\
\hline Silt & $-0.54^{*}$ & $0.26^{*}$ & $0.20^{*}$ & $0.43^{*}$ & $0.49^{*}$ & $0.46^{*}$ & $-0.88^{*}$ & 1.00 & & & & & \\
\hline Clay & $0.17^{*}$ & -0.06 & $-0.11^{*}$ & -0.15 & $-0.21^{*}$ & $-0.16^{*}$ & $-0.18^{*}$ & $-0.27^{*}$ & 1.00 & & & & \\
\hline GAD & $-0.35^{*}$ & $0.22^{*}$ & $0.16^{*}$ & $0.35^{*}$ & $0.34^{*}$ & $0.29^{*}$ & $-0.18^{*}$ & $0.23^{*}$ & $-0.13^{*}$ & 1.00 & & & \\
\hline WAD & $-0.36^{*}$ & $0.22^{*}$ & $0.17^{*}$ & $0.36^{*}$ & $0.36^{*}$ & $0.30^{*}$ & $-0.17^{*}$ & $0.23^{*}$ & $-0.15^{*}$ & $0.99^{*}$ & 1.00 & & \\
\hline$>2.0$ & $-0.37^{*}$ & $0.22^{*}$ & $0.17^{*}$ & $0.36^{*}$ & $0.36^{*}$ & $0.30^{*}$ & $-0.17^{*}$ & $0.23^{*}$ & $-0.16^{*}$ & $0.99^{*}$ & $1.00^{*}$ & 1.00 & \\
\hline $2.0-1.0$ & $0.35^{*}$ & $-0.21^{*}$ & $-0.19^{*}$ & -0.35 & $-0.37^{*}$ & $-0.29^{*}$ & $0.11^{*}$ & $-0.18^{*}$ & $0.20^{*}$ & $-0.90^{*}$ & $-0.93^{*}$ & -0.94 & 1.00 \\
\hline$<1.0$ & $0.36^{*}$ & $-0.23^{*}$ & $-0.17^{*}$ & -0.35 & $-0.35^{*}$ & $-0.29^{*}$ & $0.18^{*}$ & $-0.24^{*}$ & $0.15^{*}$ & $-0.99^{*}$ & $-1.00^{*}$ & -1.00 & $0.91^{*}$ \\
\hline
\end{tabular}

Note. *Significant correlations at 5\% probability. SD: soil density; MaP: macroporosity; MiP: microporosity; TPV: total pore volume; GH: gravimetric humidity; RP: soil resistance to penetration; OC: organic carbon; CS: carbon stock; GAD: geometric average diameter; WAD: weighted average diameter.

In the main component analysis (MCA), the number of factors to be extracted was established to explain above $70 \%$ of the total data variance (Table 2 and Figure 2), which showed covariance matrix eigenvalues greater than one (1) (Manly, 2008), with 4.71 at MC1 and 3.80 at MC2. From the percentage of the explained variance, it was observed that $\mathrm{MC} 1$ is responsible for $42.79 \%$ of the total variance, whereas $\mathrm{MC} 2$ is responsible for $34.54 \%$, which should explain the variability of the original data (Andrade, Araújo, Rosa, Gomes, \& Lobato, 2007). 


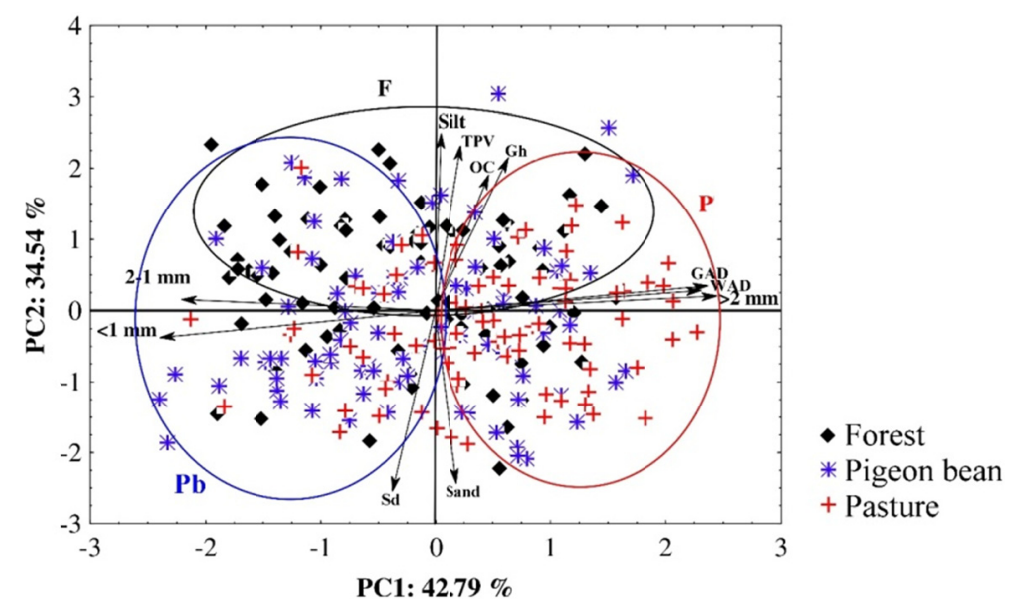

Figure 2. Factorial plan of soil attributes collected at a depth of 0.00-0.20 m in areas of Archaeological Black Earth under different uses in the region of Novo Aripuanã, Amazon. Values standardized so that the mean is zero and the distances between the scores are measured by the standard deviation.

FN: forest; FJ: pigeon pea; EN: pasture

Both the first and the second factor (Table 2) present a high percentage of explanation for the structural characteristics, aggregate stability, organic carbon and soil texture. Thus, the discrimination between the environments refers to these characteristics, with $\mathrm{MC1}$ representing the stability characteristics of the soil aggregates (GAD, WAD and classes of aggregates $>2.00 \mathrm{~mm}, 2.00-1.00 \mathrm{~mm}$ and $<1 \mathrm{~mm}$, while MC2 is the soil structure, texture and soil organic carbon characteristics (SD, TPV, GH, OC, sand and silt content).

Table 2. Correlation between each main component and analyzed variables and factorial analysis of soil attributes collected at a depth of 0.00-0.20 m, with rotational factors (Varimax) (Factor 1 and 2) corresponding in areas of Indian Black Earth in Novo Aripuanã, Amazon

\begin{tabular}{llll}
\hline \multirow{2}{*}{ Atributos } & Common Variance & \multicolumn{2}{c}{ Factor } \\
\cline { 2 - 3 } SD & 0.79 & $\mathrm{MC} 1$ & $\mathrm{MC} 2$ \\
$\mathrm{TPV}$ & 0.75 & -0.15 & $-0.86^{*}$ \\
$\mathrm{GH}$ & 0.61 & 0.09 & $0.80^{*}$ \\
OC & 0.44 & 0.25 & $0.74^{*}$ \\
Sand & 0.88 & 0.19 & $0.67^{*}$ \\
Silt & 0.88 & 0.08 & $-0.82^{*}$ \\
GAD & 0.91 & 0.03 & $0.85^{*}$ \\
WAD & 1.00 & $0.95^{*}$ & 0.11 \\
$>2.00 \mathrm{~mm}$ & 1.00 & $0.99^{*}$ & 0.09 \\
$2.00-1.00 \mathrm{~mm}$ & 0.77 & $0.99^{*}$ & 0.08 \\
$<1.00 \mathrm{~mm}$ & 0.99 & $-0.88^{*}$ & 0.06 \\
& Variance explained $(\%)$ & $-0.97^{*}$ & -0.11 \\
\hline
\end{tabular}

Note. SD: soil density; MaP: macroporosity; MiP: microporosity; TPV: total pore volume; GH: gravimetric humidity; RP: soil resistance to penetration; OC: organic carbon; CS: carbon stock; GAD: geometric average diameter; WAD: weighted average diameter; $>2.00 \mathrm{~mm}(\%)$ : class of aggregates bigger then than $2.00 \mathrm{~mm}$; 2.00-1.00 mm: class of aggregates between 2.00 and $1.00 \mathrm{~mm} ;<1.00 \mathrm{~mm}(\%)$ : class of aggregates less than 1 $\mathrm{mm}$. *Attributes with high factor loads.

In Figure 2 is shown the factorial plane of the distribution of scores in different areas studied and the arrangement of factor loadings of soil attributes collected at a depth of 0.0 to $0.20 \mathrm{~m}$, formed by main component 1 (MC1) and main component 2 (MC2). For a geometric interpretation, the weights assigned to each variable correspond to the projections to each of the coordinate axes represented by the main components (Manly, 2008). 
It is observed a greater densification of forest scores in the first and second quadrants of Figure 2, which discriminates the area under forest. Thus, soil samples collected in the forest promoted values to the attributes TPV, GH, OC and silt content above average and positively correlated with MC2. As the attributes and the sand content values below average and correlated negatively with MC2. On the other hand, soil samples collected under the area of pigeon pea are more distributed between the second and third quadrants, with attributes of aggregate classes $2.00-1.00 \mathrm{~mm}$ and $<1.00 \mathrm{~mm}$ above the average in comparison to the other environments and negatively correlated with $\mathrm{MC1}$, and GAD, WAD, and aggregate classes $>2.00 \mathrm{~mm}$, below the average and positively correlated with MC1.

Soil samples collected under the pasture area obtained an inverse behavior to those of the pigeon pea, the values being more distributed between the first and fourth quadrant, with attributes GAD, WAD and classes of aggregates $>2.00 \mathrm{~mm}$ promoting values above mean in comparison to other environments and positively correlated with MC1, while the attributes classes of aggregates $2.00-1.00 \mathrm{~mm}$ and $<1.00 \mathrm{~mm}$ had values below the mean and negatively correlated to $\mathrm{MC1}$. Nevertheless, despite the intensive management, in general the IBE present characteristics very close to the natural one (Forest), what justifies the high resistance of these to the alterations or losses of physical quality of the soil.

Thus, the discrimination between the management environments is summarized on the structural characteristics of the soil, mainly to the attributes more strongly related to the porous system of the soil. In the area of pigeon pea, there was loss of structural characteristics, with behavioral changes both to the soil porous system and to the stability of aggregates, compared to the forest environment. On the other hand, pasture area, it was observed improvement in stability of soil aggregates, which in this case may be associated with a higher level of compaction and resistance to rupture (Soares et al., 2016), and confirmed the higher values of Sd and RP compared to the soil under forest.

A very large number of variables that involve all the dynamics of the soil-plant-atmosphere system, allied to temporal and spatial variations in the field, become very complex in decision making. One option of analysis of spatial variability for the set of soil variables is the use of multivariate geostatistics. In this way, the ease of interpreting maps from the analysis is due to the reduction of the number of variables from the main components (Silva, Lima, Xavier, \& Teixeira, 2010; Alves, Queiroz, Alcântara, \& Reis, 2014). The scores derived from principal component analysis were used in geostatistics.

Figure 3 shows the experimental variogram and the classical models for adjustment of the scoring factors related to the stability of soil aggregates (MC1) and the structural characteristics of the soil texture and soil organic carbon (MC2). The parameters and cross-validation results for these models are presented in Table 3.

For the classical models proposed in the adjustment of the experimental semivariogram of the main components (Table 3), the determination coefficients were relatively high, plus low residual error, besides promoting coefficients of cross validation regressions above $98 \%$. 

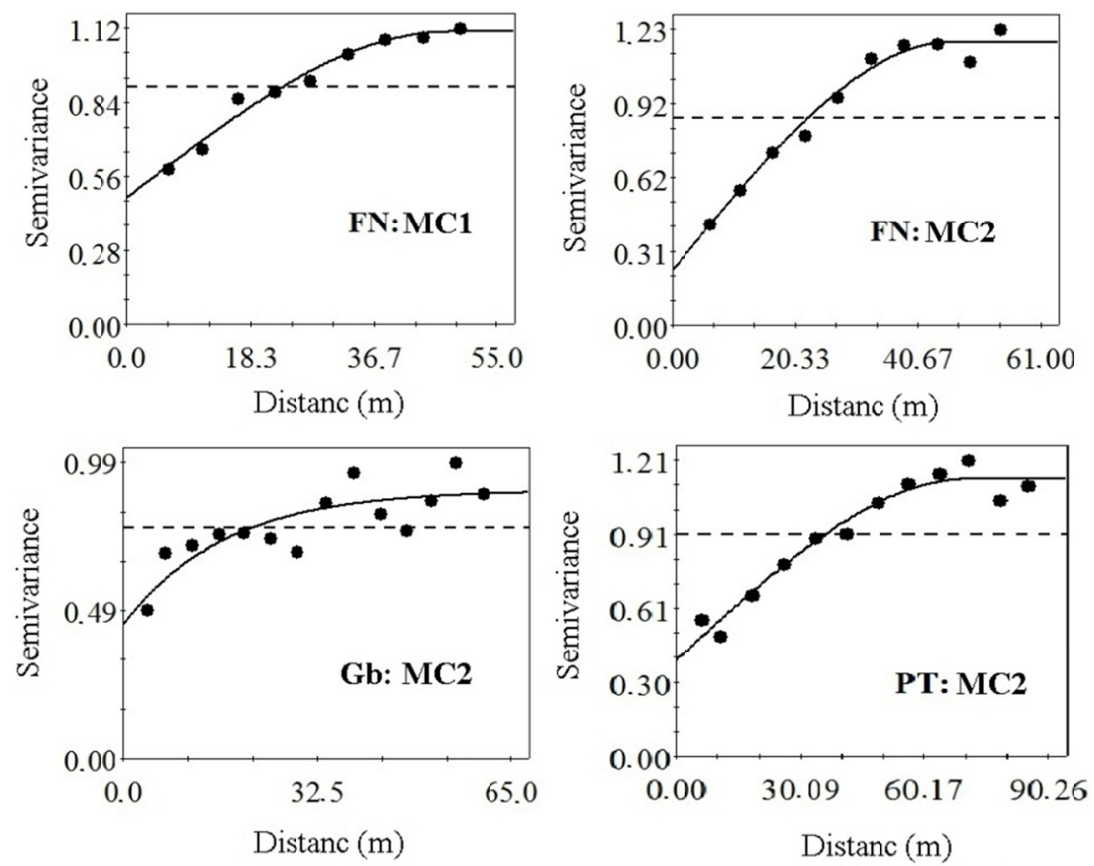

Figure 3. Parameters and models of semivariograms of the main components of the soil attributes in areas of IBE in the region of Novo Aripuanã, Amazon. FN: natural forest; FJ: pigeon pea; PT: pasture; MC1: main component related to the stability of aggregates; $\mathrm{MC} 2$ : main component related to the structural characteristics, soil texture and organic carbon of the soil

Table 3. Results of the parameters of the adjusted semivariogram models of the main components of the soil attributes in IBE in the region of Novo Aripuanã, Amazon

\begin{tabular}{|c|c|c|c|c|c|c|c|c|c|}
\hline Area & Scores & Model & $C_{0}$ & $C_{0}+C_{1}$ & DSD (\%) & $a(\mathrm{~m})$ & SQR & $\mathrm{R}^{2}$ & $\mathrm{r}$ \\
\hline \multirow{2}{*}{ FN } & $\mathrm{MC1}$ & Esf & 0.48 & 1.11 & 43.20 & 47.80 & 7.0 E-03 & 0.98 & 0.99 \\
\hline & MC2 & Esf & 0.23 & 1.18 & 19.50 & 46.30 & $1.57 \mathrm{E}-02$ & 0.98 & 0.99 \\
\hline \multirow{2}{*}{ FJ } & $\mathrm{MCl}$ & PNE & - & - & - & - & - & - & $=$ \\
\hline & MC2 & Exp & 0.45 & 0.90 & 50.0 & 16.80 & $6.86 \mathrm{E}-02$ & 0.67 & 0.98 \\
\hline \multirow{2}{*}{$\mathrm{PT}$} & $\mathrm{MC} 1$ & $\mathrm{PNE}$ & - & - & - & - & - & - & - \\
\hline & MC2 & Esf & 0.39 & 1.14 & 34.2 & 70.90 & $2.87 \mathrm{E}-02$ & 0.96 & 0.99 \\
\hline
\end{tabular}

Note. $\mathrm{C}_{0}$ : nugget effect; $\mathrm{C}_{0}+\mathrm{C}_{1}$ : landing; $\mathrm{DSD}$ : degree of spatial dependence; a: reach; SQR: residue; $\mathrm{R}^{2}$ : coefficient of determination; r: cross-validation regression coefficient; Esf: spherical model; Exp: exponential model; PNE: pure nugget effect.

There was a change of behavior of the spatial variability patterns of the main components for the evaluated environments. The degree of spatial dependence, according to the classification of Cambardella et al. (1994), was strong for the MC2 of the area under forest and moderate to the other components of the areas under study (Table 3). The spatial correlation range was lower for the MC2 of the pigeon pea area and higher for the MC2 of the pasture area.

These results indicate that the attributes related to the soil structure were influenced by the type of cover, when evaluated in relation to the forest area which, in turn, corroborates with the increase of the spatial dependence under the pasture, since the clustering of particles becomes more favorable due to the type of root system of this crop. In addition, higher the correlation ranges of the adjusted semivariogram, the better the accuracy of interpolation estimation results by ordinary kriging, making the analysis even more robust (Silva, Lima, Xavier, \& Teixeira, 2010; Alves, Queiroz, Alcântara, \& Reis, 2014).

However, the forest environment had spatial correlation dependence above $40 \mathrm{~m}$. The type of coverage may also have been a determining factor for behavioral changes in relation to the variability of attributes related to MC1 (aggregate stability). 
The main components related to the stability of the aggregates (MC1) for the environments of pigeon pea and pasture did not present spatial dependence for the sampling distances (Table 3), preventing the use of geostatistical models (José et al., 2013). As a consequence, the interpolation method of the inverse of the square of the distance was used to semivariograms that did not present spatial dependence. On the other hand, the models and parameters of semivariograms that presented spatial dependence were interpolated by means of ordinary kriging. Both methods were used in the mapping of attributes related to the main components.

The maps of spatial variability patterns show a distribution of soil characteristics related to MC1 and MC2 (Figure 4). Here the values were standardized in such a way that the mean became zero. Thus, under the forest, there is predominance of above-average values for both MC1 and MC2. Thus, the darkest area of the MC1 map reflects regions of the area with the greatest value of GAD, WAD and aggregate class $>2.00 \mathrm{~mm}$, and lower value for aggregate classes $2.00-1.00 \mathrm{~mm}$ and $<1.00 \mathrm{~mm}$, since these attributes present a negative correlation with MC1. In addition, the darker area of the MC2 map reflects higher GH, TPC, OC and silt content and lower $\mathrm{Sd}$ and sand content, corroborating the results presented in the previous section.
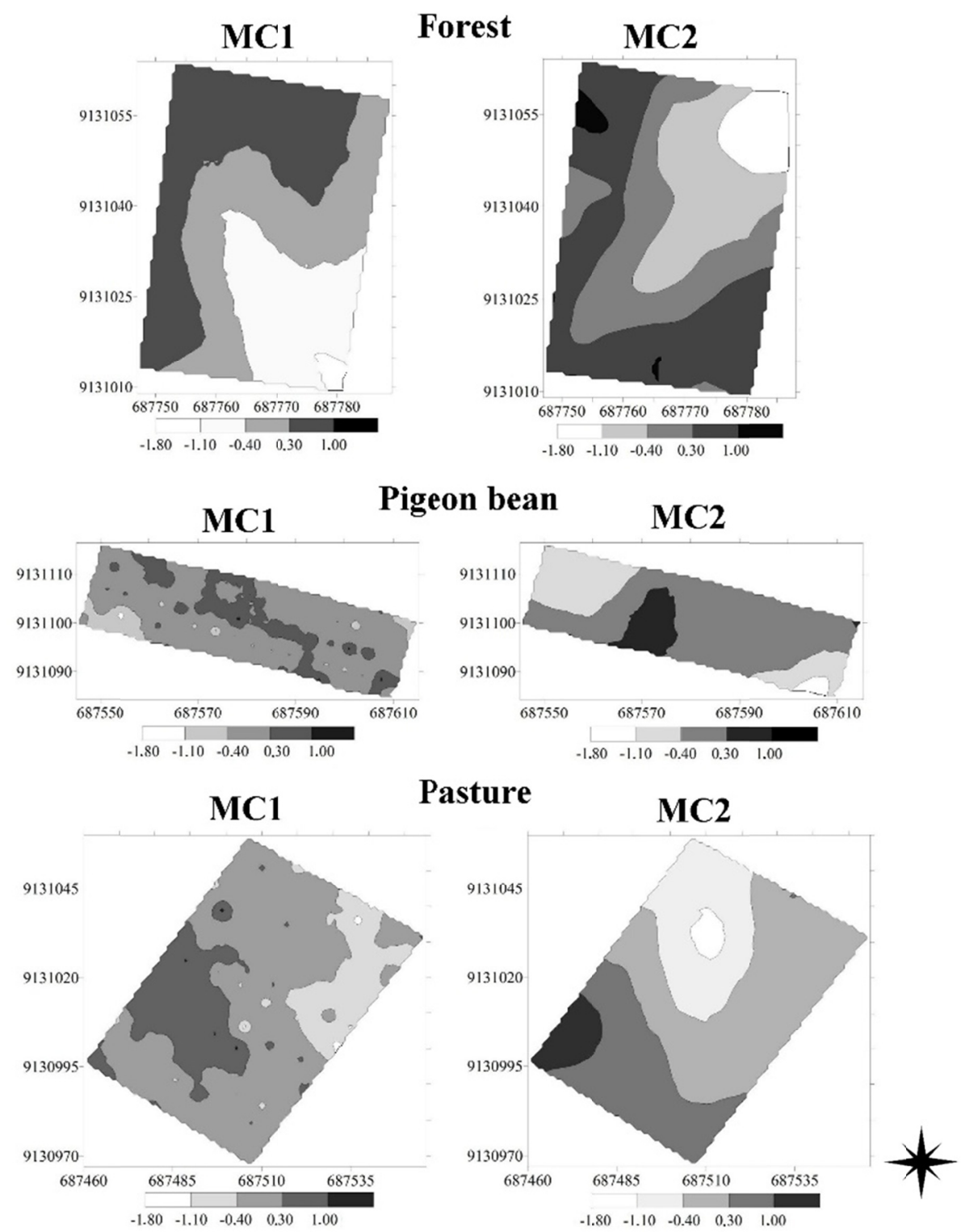

Figure 4. Spatial distribution of the main components related to the stability of the aggregates (MC1) and the structural characteristics, texture and soil organic carbon (MC2) in environments of Archaeological Black Earth in the region of Novo Aripuanã, Amazon 
Both soil under cover of pigeon pea and pasture presented predominantly close to average values for both main components, except for MC2 under pasture, which promoted attributes related to this component above average values. Thus, the cultivation of the pigeon pea influenced little under the variability of soil attributes related to $\mathrm{MC2}$, as well as pasture for $\mathrm{MC} 1$, but that the use of the soil under pasture promoted influence to the attributes related to MC2 (soil structural characteristics, texture and soil organic carbon), which resulted in improvement in these characteristics with respect to physical quality scores for these are ground.

\section{Conclusion}

The variability of soil attributes under forest presented above-average values for main component 1 (MC1) and main component 2 (MC2). Land use under pigeon pea had little influence on the variability of the main components, presenting values of the attributes related to these components near the mean values, while the pasture promoted influence only the attributes related to main component 2 (MC2).

\section{References}

Alves, S. M. F., Queiroz, D. M., Alcântara, G. R., \& Reis, E. F. (2014). Variabilidade espacial de atributos físico-químicos do solo usando técnicas de análise de componentes principais e geoestatística. Bioscience Journal, 30(1), 22-30.

Andrade, E. M., Araújo, L. F. P., Rosa, M. F., Gomes, R. B., \& Lobato, F. A. O. (2007). Fatores determinantes da qualidade das águas superficiais na bacia do Alto Acaraú, Ceará, Brasil. Ciência Rural, 37, 1791-1797. https://doi.org/10.1590/S0103-84782007000600045

Andrade, R. S., Stone, L. F., \& Silveira, P. M. (2009). Culturas de cobertura e qualidade física de um Latossolo em plantio direto. Revista Brasileira Engenharia Agrícola e Ambiental, 13, 411-418. https://doi.org/ $10.1590 /$ S1415-43662009000400007

Aquino, R. E., Campos, M. C. C., Junior, J. M., Oliveira, I. A., Teixeira, D. D. B., \& Cunha, J. M. (2015). Use of scaled semivariograms in the planning sample of soil physical properties in southern Amazonas, Brazil. Revista Brasileira de Ciência do Solo, 39, 21-30. https://doi.org/10.1590/01000683rbcs20150524

Aratani, R. G., Freddi, O. S., Centurion, J. F., \& Andrioli, I. (2009). Qualidade física de um Latossolo Vermelho Acriférrico sob diferentes sistemas de uso de manejo. Revista Brasileira de Ciência do Solo, 33, 677-687. https://doi.org/10.1590/S0100-06832009000300020

Cambardella, C. A., Moorman, T. B., Novak, J. M., Parkin, T. B., Karlen, D. L., Turco, R. F., \& Konopka, A. E. (1994). Field-scale variability of soil properties in Central Iowa. Soil Science Society of America Journal, 58, 1501-11. https://doi.org/10.2136/sssaj1994.03615995005800050033x

EMBRAPA (Empresa Brasileira de Pesquisa Agropecuária). (2011). Manual de métodos de análise de solo (2nd ed., p. 230). Rio de Janeiro: Embrapa Solo.

Glaser, B., \& Birk, J. J. (2012). State of the scientific knowledge on properties and genesis of Anthropogenic Dark Earths in Central Amazonia (Terra Preta de Índio). Geochimica et Cosmochimica Acta, 82, 39-51. https://doi.org/10.1016/j.gca.2010.11.029

Golden Software Inc. (1999). SURFER for Windows, Realese 8.0: Contouring and 3D surface mapping for scientist's engineers, user's guide. New York, USA.

Isaaks, E. H., \& Srivastava, R. M. (1989). An introduction to applied geostatistics (p. 561). New York, Oxford University Press.

José, J. V., Rezende, R., Freitas, P. S. L., Hongyu, K., Perboni, A., Marques, P. A. A., ... Coelho, R. D. (2013). Análise multivariada e geoestatística de variáveis físico-hídricas de diferentes solos. Water Resources and Irrigation Management, 2(3), 121-129.

Kemper, W. D., \& Chepil, W. S. (1965). Size distribution of aggregates. In C. A. Black, D. D. Evans, J. L. White, L. E. Ensminger, \& F. E. Clark (Eds.), Methods of soil analysis-Physical and mineralogical properties, including statistics of measurement and sampling (pp. 499-510). Madison, American Society of Agronomy.

Manly, B. J. F. (2008). Métodos estatísticos multivariados: Uma introdução (3rd ed.). Porto Alegre: Bookman.

Oliveira, I. A., Campos, M. C. C., Freitas, L., \& Soares, M. D. R. (2015). Caracterização de solos sob diferentes usos na região sul do Amazonas. Acta Amazônica, 45(1), 1-12. https://doi.org/10.1590/S0044-59672 005000100002 
Sales, R. P., Portugal, A. F., Moreira, J. A. A., Kondo, M. K., \& Pegoraro, R. F. (2016). Qualidade física de um Latossolo sob plantio direto e preparo convencional no semiárido. Revista Ciência Agronômica, 47(3), 429-438. https://doi.org/10.5935/1806-6690.20160052

Silva, D. M. P., Campos, M. C. C., Franciscon, U., Alho, L. C., Santos, L. A. C., Neto, P. P., ... Souza, Z. M. (2016). Spatial variability of soil properties in archeological dark earth sites under cacao cultivation. Revista Brasileira de Ciência do Solo, 40, 1-12. https://doi.org/10.17666/319114/2016

Silva, M. O., Freire, M. B. G. S., Mendes, M. A. S., Freire, F. J., Campos, M. C. C., \& Amorim, L. B. (2010). Discriminação de diferentes classes de solos irrigados com águas salinas, na região de Mossoró, RN, com o uso de análise multivariada. Ambiência, 6(2), 261-270.

Silva, S. A., Lima, J. S. S., Xavier, A. C., \& Teixeira, M. M. (2010). Variabilidade espacial de atributos químicos de um latossolo vermelho-amarelo húmico cultivado com café. Revista Brasileira de Ciência do Solo, 34, 15-22. https://doi.org/10.1590/S0100-06832010000100002

Soares, M. D. R., Campos, M. C. C., Oliveira, I. A., Cunha, J. M., Santos, L. A. C., Fonseca, J. S., \& Souza, Z. M. (2016). Atributos físicos do solo em áreas sob diferentes sistemas de usos na região de Manicoré, AM. Revista Ciências Agrárias, 59(1), 9-15. https://doi.org/10.4322/rca.2020

Yeomans, J. C., \& Bremner, J. M. (1988). A rapid and precise method for routine determination of organic carbon in soil. Communication in Soil Science and Plant Analysis, 19, 1467-1476. https://oi.org/10.1080/ 00103628809368027

\section{Copyrights}

Copyright for this article is retained by the author(s), with first publication rights granted to the journal.

This is an open-access article distributed under the terms and conditions of the Creative Commons Attribution license (http://creativecommons.org/licenses/by/4.0/). 